\title{
Monitoring of trace element content in tap water from Karachuny Reservoir, Kryvyi Rih city
}

\author{
Viktoriia Stoliarenko ${ }^{1, *}$, Marina Chernova $^{2}$, and Olga Yakovchuk $^{1}$ \\ ${ }^{1}$ Kryvyi Rih State Pedagogical University, 54 Gagarina Ave., Kryvyi Rih, Ukraine \\ ${ }^{2}$ Public utility "Kryvbasvodokanal”, 6A Jesenina Str., 6A, Kryvyi Rih, Ukraine
}

\begin{abstract}
Control of the trace element content in tap water is particularly important for large industrial regions. The estimation of $\mathrm{Cd}, \mathrm{Pb}, \mathrm{Cu}, \mathrm{As}, \mathrm{Ni}, \mathrm{Zn}, \mathrm{Mn}, \mathrm{Hg}$, Se and Co concentration in the tap water of Kryvyi Rih city (Karachuny Reservoir) was accomplished using electrochemical methods, the most popular methods for determining the content of trace elements in natural objects and tap water. A simple and rapid method to determine trace elements in the tap water (Kryvyi Rih city) by inversion-voltammetry has been used. The concentration of trace elements was measured by voltammetricanalyzer AVA-2 device that implements the method of inversion voltammetry on a solid rotating electrode made of carbon material. The monitoring of the trace element content in the water of the Karachuny reservoir was carried out on a monthly basis between September 2018 and August 2019. The article presents the obtained voltamperograms of some trace elements, describes content of the trace element in tap water during the year (12 data for each trace element) and analyzes the compliance of drinking water in the city of Kryvyi Rih to the standards and normative indicators of drinking water quality.
\end{abstract}

\section{Introduction}

The safety of water supply is one of the main factors of national security of the country. The quality of tap water is carefully monitored at the state level, as the health and life of the population depends on it $[1,2]$.

Drinking water is intended for human consumption to meet physiological, hygienic, household and economic needs, as well as for the production of products, so its composition according to organoleptic, microbiological, parasitological, chemical, physical and radiation indicators must meet the established hygienic requirements in the State Sanitary and Epidemiological Service of Ukraine 2.2.4-171-10 "Hygienic requirements for drinking water intended for human consumption". If the water does not meet the standards, it is cleaned and disinfected [3].

Much attention is paid to the quality of drinking water in Ukraine and abroad in the works of such scientists as I. Gushchuk, T. Kotova, I. Andrusishina, A. Serdyuk and others [4-6].

The quality of tap water is monitored with a certain frequency depending on the type of control: complete control - once a year; reduced periodic inspection - once or twice a month; reduced production control from once a month to once a day [1].

The quality of tap water is especially carefully monitored in regions with agricultural and industrial complexes, as typical problems of water quality for them are increased mineralization, hardness, and the presence of harmful impurities. All these consequences of negative anthropogenic impact on the state of water cause not only the deterioration of the taste of tap water, but first of all make it dangerous for consumption without additional purification measures.

Kryvyi Rih is one of such regions with powerful industrial complex and environmental issues. The water basin of the city has a considerable technogenic loading, which is related to the activities of the main contaminators, including the metallurgical production of "ArcelorMittal Kryviy Rih PLC", "Pivnichnyi Ore Mining and Industrial Complex PLC", "KryvbasIronOre Complex PLC", "HeidelbergCement Ukraine PLC" and others.

One of the important components in the composition of water that directly affects the human body are trace elements such as cadmium, plumbum, cuprum, arsenic, nickel, zinc, manganese, mercury, selenium, and cobalt. Some of them are vital microelements for living organisms, as they take an active part in biochemical processes. However, even a slight excess of their maximum permissible concentrations is very dangerous for the human body.

Plumbum has the property to accumulate in the tissues of the body, and it is manifested by the signs of damage of the central and peripheral nervous system, intestines and kidneys. It also blocks enzymes and prevents the formation of vitamins.

Arsenic is very poisonous to humans, causes widespread forms of cancer, and accumulating in the thyroid gland it becomes a cause of endemic goiter. In the case of chronic manganese poisoning, there is

* Corresponding author: st_viki@ukr.net 
deterioration in the functioning of the central nervous system, changes in functions in the cardiovascular system, esophagus and liver.

Zinc is a very important trace element that acts as a cofactor of about 300 enzymes and it is an immunostimulator, but exceeding the permissible norms causes acute forms of poisoning. Cadmium is a very toxic element for the human body and it has the ability to accumulate and to affect the liver and kidneys, and this element is carcinogenic.

Cuprum is a part of important enzymes and proteins and it promotes growth and development of the human body, participates in hematopoiesis, and immune responses. Excessive intake of cuprum in the body causes bronchial asthma, kidney disease, liver disease, and intoxication.

Nickel is a part of some proteins, RNA and DNA, and its excess has a toxic and carcinogenic effect. Cobalt is a part of vitamin $B_{12}$, takes part in the processes of hematopoiesis. The excess of cobalt causes dermatitis, cardiovascular failure, and affects the respiratory system. Mercury affects the cardiovascular and nervous systems and kidneys.

Selenium is part of many biologically active compounds, participates in the regulation of metabolism, metabolism of fats, proteins and carbohydrates, as well as in oxidation-reduction processes. Selenium overdose can damage the respiratory, excretory and nervous systems [7-10].

Therefore, the significant impact of trace elements on the human body makes it important to systematically control of their content in the environment, in particular, in tap water and further purification of water from excess trace elements if it is necessary.

\section{Materials and methods. Gathering samples}

Voltammetry is one of the most popular methods for determining the content of trace elements in natural objects and drinking water, which is associated with the ability to detect low concentrations of elements using this method with high accuracy [11-14]. In order to determine the content of trace elements in drinking water from the Karachuny Reservoir it was used the method of inverse voltammetry.

\subsection{The essence of the method of determining trace elements}

The inversion-voltammetric method is based on the ability of an element to be analyzed electrochemically to accumulate on the surface or in the volume of an indicator working electrode and to dissolve in the process of anodic or cathodic polarization at a specific potential characteristic of each element.

The peak height of the element registered on the voltammogram is proportional to the mass fraction of the element in the solution.

The content of trace elements in drinking water samples is determined automatically by processing the values of the element's analytical signals on voltammograms of a series of solutions.

\subsection{Device}

The concentration of trace elements was measured by voltammetricanalyzer AVA-2 from Research and Development enterprise "Byrevestnik".

The AVA-2 analyzer is an electrochemical device that implements the method of inversion voltammetry on a solid rotating electrode made of carbon material.

The measuring cycle of the AVA-2 voltammetric analyzer includes four stages:

- the first stage - electrochemical regeneration of the surface of the working electrode (potential from 0 to $+650 \mathrm{mV}$ );

- the second stage - the electrochemical accumulation of trace elements on the surface of the working electrode (potential from 0 to $-1500 \mathrm{mV}$ );

- the third stage - sedation of the solution (potential from 0 to $-1500 \mathrm{mV}$ );

- the fourth stage is measurement, the current-potential curve is built and recorded (potential from 0 to $1500 \mathrm{mV}$ ).

The current-potential dependence is recorded in the form of a graph in which the position of the current peaks on the potential axis qualitatively characterizes the trace elements which is determinated (each element has its own dissolution peak). The height of the peak is proportional to the concentration of trace elements in the solution.

The AVA-2 analyzer measures the concentration of metal ions in aqueous solutions in the range, $\mathrm{mcg} / \mathrm{dm}^{3}$ : 0,005-100 (Hg); 1-10000 (Zn); 1-200 (Pb, Cd, Cu); 11000 (As).

Sensitivity limit, $\mathrm{mcg} / \mathrm{dm}^{3}-0,01(\mathrm{Cd}, \mathrm{Pb}, \mathrm{Cu}, \mathrm{Zn})$; 0,2 (As), 0,005 (Hg).

\subsection{Reagents and Technique}

\subsubsection{Reagents}

All of the used reagents were of purest quality possible (analytical grade).

Before use, distilled water was further purified by distillation with an alkaline solution of potassium permanganate.

\subsubsection{Technique}

The standard technique measurements of the mass concentration of toxic metal ions in drinking and surface water by inversion voltammetry was chosen for the experimental determination of the trace elements cadmium, plumbum, cuprum, arsenic, nickel, zinc, manganese, mercury, selenium and cobalt in the tap water from the Karachuny Reservoir [15].

The standard additive method was used to determine the mass concentration of element in drinking water samples. This technique measurements does not require 
a calibration schedule.

The method of standard addition is based on the detection of cycles voltammperograms for the same measurement parameters of a series of three solutions:

1) background electrolyte (background);

2) sample prepared for measurements;

3) the same sample into which the solution-additive of the measured element is introduced, with a known mass concentration.

The volume of the additive solution depends on the content of the element, which is determined in the sample. It is added in such an amount that the height of the characteristic peak of the solution with the additive has to increase in 2-3 times in the sample with the added additive solution (solution 3 ) in comparison with the height of the peak in the experimental solution (solution 2).

The additive solution can be administered several times, but the total volume should not exceed $10 \%$ of the sample volume analyzed.

The result of three measurement cycles is a voltammogram, which determines the quantitative content of the trace element in solution.

Characteristic potential peaks for trace elements in voltammograms:

Peak potential (Zn) $-1150 \ldots-800 \mathrm{mV}$

Peak potential $(\mathrm{Cd})-600 \ldots-450 \mathrm{mV}$

Peak potential $(\mathrm{Pb})-450 \ldots-300 \mathrm{mV}$

Peak potential $(\mathrm{Cu})-150 \ldots-20 \mathrm{mV}$

Peak potential (Mn) $-1550 \ldots-1450 \mathrm{mV}$

Peak potential $(\mathrm{Hg}) 450 \ldots 650 \mathrm{mV}$

Peak potential (As) $-100 \ldots 300 \mathrm{mV}$

Peak potential (Ni) $1090 \ldots 1180 \mathrm{mV}$

\subsubsection{Gathering samples}

The main source of tap water in Kryvyi Rih is the Karachuny Reservoir. The monitoring of the trace element content in the water from the Karachuny reservoir was carried out on a monthly from September 2018 to August 2019.

Selection, storage and handling of drinking water samples were performed in accordance with DSTU ISO 5667-6 and DSTU ISO 5667-3.

\section{Results and discussion}

The content of trace elements in tap water from the Karachuny Reservoir (Kryvyi Rih) was evaluated using inversion voltammetry method.

During the experiment, three consecutive measurements were made for a sample of drinking water for each element. According to the received voltammograms, the presence of a certain trace element and quantitative characteristics of its content were determined in the sample. Figures 1-2 show the voltammograms obtained for zinc and plumbum (voltage (v) with the current (a)).

The resulting voltammograms contain three curves in the coordinates voltage $(\mathrm{V})$ with the current $(\mathrm{A})$, which are indicated by different colors.

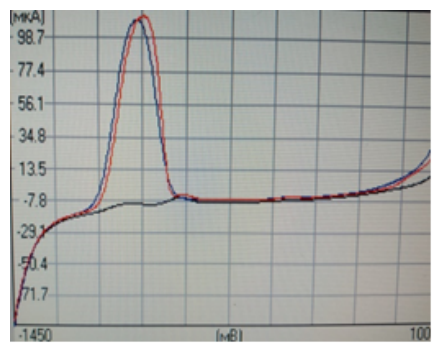

Fig. 1. Voltammogram of the trace element $\mathrm{Zn}$ in tap water.

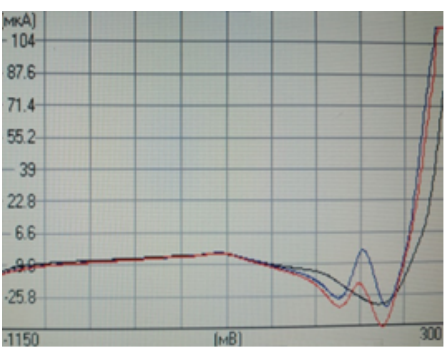

Fig. 2. Voltammogram of the trace element $\mathrm{Pb}$ in tap water.

The black curve reflects the value of the background solution. Red curve corresponds to the sample of the water under being tested. Blue curve corresponds to the water sample that is being investigated with the added solution-additive.

The content of trace elements in the samples of the studied tap water was calculated by automatic processing the analytical signals of the element on voltamperograms in a series of solutions. The established data of the trace elements content in tap water from the Karachuny Reservoir are presented in four tables according to the season of autumn, winter, spring and summer (Table 14).

Table 1. Concentrations of essential trace elements in Karachuny Reservoir (autumn 2018).

\begin{tabular}{|c|c|c|c|}
\hline \multirow[t]{2}{*}{ Elements } & \multicolumn{3}{|c|}{$\begin{array}{c}\text { Concentrations of trace elements in } \\
\mathbf{m g} / \mathbf{d m}^{3} \pm \text { S.D. }\end{array}$} \\
\hline & September & October & November \\
\hline Mn & $2,3 \cdot 10^{-2} \pm 1,5 \cdot 10^{-3}$ & $2,6 \cdot 10^{-2} \pm 3,1 \cdot 10^{-3}$ & $2,1 \cdot 10^{-2} \pm 1,5 \cdot 10^{-3}$ \\
\hline $\mathbf{C u}$ & $6,8 \cdot 10^{-3} \pm 2,6 \cdot 10^{-4}$ & $8,1 \cdot 10^{-3} \pm 3,8 \cdot 10^{-4}$ & $7,8 \cdot 10^{-3} \pm 7,0 \cdot 10^{-4}$ \\
\hline Zn & $3,7 \cdot 10^{-3} \pm 5,8 \cdot 10^{-4}$ & $3,7 \cdot 10^{-3} \pm 5,8 \cdot 10^{-4}$ & $3,7 \cdot 10^{-3} \pm 5,8 \cdot 10^{-4}$ \\
\hline Cd & - & - & - \\
\hline As & $4,7 \cdot 10^{-3} \pm 5,8 \cdot 10^{-4}$ & $4,7 \cdot 10^{-3} \pm 5,8 \cdot 10^{-4}$ & $5,0 \cdot 10^{-3} \pm 1,0 \cdot 10^{-4}$ \\
\hline $\mathrm{Hg}$ & $4,7 \cdot 10^{-4} \pm 5,6 \cdot 10^{-5}$ & $4,3 \cdot 10^{-4} \pm 5,6 \cdot 10^{-5}$ & $3,3 \cdot 10^{-4} \pm 5,6 \cdot 10^{-5}$ \\
\hline $\mathbf{P b}$ & $7,5 \cdot 10^{-3} \pm 3,5 \cdot 10^{-4}$ & $6,7 \cdot 10^{-3} \pm 5,7 \cdot 10^{-4}$ & $7,8 \cdot 10^{-3} \pm 3,1 \cdot 10^{-4}$ \\
\hline Co & $\leq 5,0 \cdot 10^{-4}$ & $\leq 5,0 \cdot 10^{-4}$ & $\leq 5,0 \cdot 10^{-4}$ \\
\hline $\mathbf{N i}$ & $7,3 \cdot 10^{-3} \pm 5,8 \cdot 10^{-4}$ & $6,3 \cdot 10^{-3} \pm 5,4 \cdot 10^{-4}$ & $6,3 \cdot 10^{-3} \pm 5,8 \cdot 10^{-4}$ \\
\hline $\mathrm{Se}$ & $\leq 5,0 \cdot 10^{-4}$ & $\leq 5,0 \cdot 10^{-4}$ & $\leq 5,0 \cdot 10^{-4}$ \\
\hline
\end{tabular}

The results obtained in the autumn months showed a high concentration of manganese in water relative to concentration of other trace elements; the lack of detectable amounts of cadmium and low constant values for cobalt and selenium.

The trend in the distribution of trace element concentrations that was established for the autumn period repeated in the results of studies of the trace elements content in drinking water in the winter months again. And it did not change significantly in the data obtained in spring and summer studies. 
Table 2. Concentrations of essential trace elements in Karachuny Reservoir (winter 2018-2019).

\begin{tabular}{|c|c|c|c|}
\hline \multirow{2}{*}{$\begin{array}{c}\text { Ele- } \\
\text { ments }\end{array}$} & \multicolumn{3}{|c|}{ Concentrations of trace elements in mg/dm } \\
\cline { 2 - 4 } & December & January & February \\
\hline $\mathbf{M n}$ & $1,6 \cdot 10^{-2} \pm 1,2 \cdot 10^{-3}$ & $2,1 \cdot 10^{-2} \pm 3,5 \cdot 10^{-3}$ & $2,4 \cdot 10^{-2} \pm 1,0 \cdot 10^{-3}$ \\
\hline $\mathbf{C u}$ & $6,4 \cdot 10^{-3} \pm 6,0 \cdot 10^{-4}$ & $6,6 \cdot 10^{-3} \pm 3,0 \cdot 10^{-4}$ & $6,7 \cdot 10^{-3} \pm 8,5 \cdot 10^{-4}$ \\
\hline $\mathbf{Z n}$ & $3,3 \cdot 10^{-3} \pm 5,8 \cdot 10^{-4}$ & $2,7 \cdot 10^{-3} \pm 6,1 \cdot 10^{-4}$ & $2,7 \cdot 10^{-3} \pm 5,8 \cdot 10^{-4}$ \\
\hline $\mathbf{C d}$ & - & - & - \\
\hline $\mathbf{A s}$ & $3,3 \cdot 10^{-3} \pm 5,8 \cdot 10^{-4}$ & $3,3 \cdot 10^{-3} \pm 5,8 \cdot 10^{-4}$ & $3,3 \cdot 10^{-3} \pm 5,8 \cdot 10^{-4}$ \\
\hline $\mathbf{H g}$ & $2,7 \cdot 10^{-4} \pm 5,6 \cdot 10^{-5}$ & $2,3 \cdot 10^{-4} \pm 5,6 \cdot 10^{-5}$ & $2,3 \cdot 10^{-4} \pm 5,6 \cdot 10^{-5}$ \\
\hline $\mathbf{P b}$ & $6,1 \cdot 10^{-3} \pm 2,0 \cdot 10^{-4}$ & $6,7 \cdot 10^{-3} \pm 2,0 \cdot 10^{-4}$ & $6,1 \cdot 10^{-3} \pm 2,0 \cdot 10^{-4}$ \\
\hline $\mathbf{C o}$ & $\leq 5,0 \cdot 10^{-4}$ & $\leq 5,0 \cdot 10^{-4}$ & $\leq 5,0 \cdot 10^{-4}$ \\
\hline $\mathbf{N i}$ & $6,3 \cdot 10^{-3} \pm 5,8 \cdot 10^{-4}$ & $5,7 \cdot 10^{-3} \pm 5,8 \cdot 10^{-4}$ & $5,3 \cdot 10^{-3} \pm 5,8 \cdot 10^{-4}$ \\
\hline $\mathbf{S e}$ & $\leq 5,0 \cdot 10^{-4}$ & $\leq 5,0 \cdot 10^{-4}$ & $\leq 5,0 \cdot 10^{-4}$ \\
\hline
\end{tabular}

Table 3. Concentrations of essential trace elements in Karachuny Reservoir (spring 2019).

\begin{tabular}{|c|c|c|c|}
\hline \multirow{2}{*}{ Elements } & \multicolumn{3}{|c|}{$\begin{array}{c}\text { Concentrations of trace elements in } \\
\text { mg/dm }\end{array}$} \\
\cline { 2 - 4 } & March & April & May \\
\hline Mn & $3,0 \cdot 10^{-2} \pm 1,5 \cdot 10^{-3}$ & $3,5 \cdot 10^{-2} \pm 1,2 \cdot 10^{-3}$ & $2,5 \cdot 10^{-2} \pm 2,1 \cdot 10^{-3}$ \\
\hline Cu & $9,7 \cdot 10^{-3} \pm 2,0 \cdot 10^{-4}$ & $9,5 \cdot 10^{-3} \pm 5,3 \cdot 10^{-4}$ & $8,4 \cdot 10^{-3} \pm 4,2 \cdot 10^{-4}$ \\
\hline $\mathbf{Z n}$ & $3,7 \cdot 10^{-3} \pm 5,8 \cdot 10^{-4}$ & $3,7 \cdot 10^{-3} \pm 5,8 \cdot 10^{-4}$ & $3,3 \cdot 10^{-3} \pm 5,8 \cdot 10^{-4}$ \\
\hline Cd & - & - & - \\
\hline As & $3,7 \cdot 10^{-3} \pm 5,8 \cdot 10^{-4}$ & $3,7 \cdot 10^{-3} \pm 5,8 \cdot 10^{-4}$ & $3,0 \cdot 10^{-3} \pm 0$ \\
\hline $\mathbf{H g}$ & $3,7 \cdot 10^{-4} \pm 5,8 \cdot 10^{-5}$ & $4,0 \cdot 10^{-4} \pm 1 \cdot 10^{-4}$ & $3,7 \cdot 10^{-4} \pm 5,8 \cdot 10^{-5}$ \\
\hline $\mathbf{P b}$ & $8,0 \cdot 10^{-3} \pm 4,6 \cdot 10^{-4}$ & $8,2 \cdot 10^{-3} \pm 3,0 \cdot 10^{-4}$ & $7,6 \cdot 10^{-3} \pm 6,2 \cdot 10^{-4}$ \\
\hline $\mathbf{C o}$ & $\leq 5,0 \cdot 10^{-4}$ & $\leq 5,0 \cdot 10^{-4}$ & $\leq 5,0 \cdot 10^{-4}$ \\
\hline $\mathbf{N i}$ & $7,3 \cdot 10^{-3} \pm 5,8 \cdot 10^{-4}$ & $6,3 \cdot 10^{-3} \pm 5,8 \cdot 10^{-4}$ & $5,3 \cdot 10^{-3} \pm 5,8 \cdot 10^{-4}$ \\
\hline Se & $\leq 5,0 \cdot 10^{-4}$ & $\leq 5,0 \cdot 10^{-4}$ & $\leq 5,0 \cdot 10^{-4}$ \\
\hline
\end{tabular}

Table 4. Concentrations of essential trace elements in Karachuny Reservoir (summer 2019).

\begin{tabular}{|c|c|c|c|}
\hline \multirow{2}{*}{ Elements } & \multicolumn{3}{|c|}{$\begin{array}{c}\text { Concentrations of trace elements in } \\
\text { mg/dm }\end{array}$. } \\
& \multicolumn{3}{|c|}{ S.D. } \\
\cline { 2 - 4 } & June & July $^{-1}$ & August \\
\hline Mn & $2,8 \cdot 10^{-2} \pm 4,7 \cdot 10^{-3}$ & $2,9 \cdot 10^{-2} \pm 1,5 \cdot 10^{-3}$ & $3,4 \cdot 10^{-2} \pm 5,8 \cdot 10^{-3}$ \\
\hline $\mathbf{C u}$ & $5,8 \cdot 10^{-3} \pm 4,2 \cdot 10^{-4}$ & $6,1 \cdot 10^{-3} \pm 2,5 \cdot 10^{-4}$ & $5,8 \cdot 10^{-3} \pm 5,5 \cdot 10^{-4}$ \\
\hline $\mathbf{Z n}$ & $2,7 \cdot 10^{-3} \pm 5,8 \cdot 10^{-4}$ & $3,0 \cdot 10^{-3} \pm 0$ & $2,7 \cdot 10^{-3} \pm 5,8 \cdot 10^{-4}$ \\
\hline $\mathbf{C d}$ & - & - & - \\
\hline $\mathbf{A s}$ & $4,3 \cdot 10^{-3} \pm 5,8 \cdot 10^{-4}$ & $3,3 \cdot 10^{-3} \pm 5,8 \cdot 10^{-4}$ & $4,0 \cdot 10^{-3} \pm 0$ \\
\hline $\mathbf{H g}$ & $2,7 \cdot 10^{-4} \pm 5,8 \cdot 10^{-5}$ & $2,0 \cdot 10^{-4} \pm 0$ & $2,7 \cdot 10^{-4} \pm 5,8 \cdot 10^{-5}$ \\
\hline $\mathbf{P b}$ & $2,9 \cdot 10^{-3} \pm 4,0 \cdot 10^{-4}$ & $4,0 \cdot 10^{-3} \pm 3,8 \cdot 10^{-4}$ & $2,6 \cdot 10^{-3} \pm 3,8 \cdot 10^{-4}$ \\
\hline $\mathbf{C o}$ & $\leq 5,0 \cdot 10^{-4}$ & $\leq 5,0 \cdot 10^{-4}$ & $\leq 5,0 \cdot 10^{-4}$ \\
\hline $\mathbf{N i}$ & $5,3 \cdot 10^{-3} \pm 5,8 \cdot 10^{-4}$ & $6,3 \cdot 10^{-3} \pm 5,8 \cdot 10^{-4}$ & $6,7 \cdot 10^{-3} \pm 5,8 \cdot 10^{-4}$ \\
\hline $\mathbf{S e}$ & $\leq 5,0 \cdot 10^{-4}$ & $\leq 5,0 \cdot 10^{-4}$ & $\leq 5,0 \cdot 10^{-4}$ \\
\hline
\end{tabular}

In this way, monitoring of the trace element content in tap water showed that manganese, cuprum, zinc, arsenic, mercury, plumbum, nickel, cobalt and selenium were present in the tap water samples, but the concentrations of these elements were lower than the maximum levels at State Sanitary Rules and Regulations (Table 5). Cobalt and selenium were found in concentrations that were low enough for these elements. Cadmium was not in all samples or it was in quantities below the capability of the instrument used.

Figure 3 and figure 4 show the monitoring of trace elements in tap water from the Karachuny Reservoir in the period from September 2018 to August 2019.

The concentration of manganese in drinking water is the highest among all trace elements that have been studied. One of the main reasons for the increase in the manganese content in the natural waters of industrial regions is the technogenic pollution of water by industrial wastewater. This is a typical situation for industrial regions such as Krivorozhsky district. However, the concentration of manganese in the drinking water of Karachuny Reservoir does not exceed the maximum permissible concentration for this microelement $\left(0.005 \mathrm{mg} / \mathrm{dm}^{3}\right)$ and stays in the range $1,6 \cdot 10^{-2}-3,5 \cdot 10^{-2} \mathrm{mg} / \mathrm{dm}^{3}$.

Table 5. The intervals of concentrations of trace elements in tap water during the autumn of 2018 - summer 2019.

\begin{tabular}{|c|c|c|c|}
\hline \multirow{2}{*}{$\begin{array}{c}\text { Name of } \\
\text { trace } \\
\text { elements }\end{array}$} & $\begin{array}{c}\text { Standard of the } \\
\text { permissible limits of } \\
\text { trace elements, } \\
\text { mg/dm }\end{array}$ & \multicolumn{2}{|c|}{$\begin{array}{c}\text { Concentrations of } \\
\text { trace elements in } \\
\text { mg/dm }\end{array}$} \\
\cline { 3 - 4 } & $\leq 0,05(0,5)^{1,}$ & max & min \\
\hline $\mathrm{Mn}$ & $\leq 1,0$ & $9,5 \cdot 10^{-2}$ & $1,6 \cdot 10^{-2}$ \\
\hline $\mathrm{Cu}$ & $\leq 1,0$ & $3,7 \cdot 10^{-3}$ & $5,8 \cdot 10^{-3}$ \\
\hline $\mathrm{Zn}$ & $\leq 0,001$ & - & $2,7 \cdot 10^{-3}$ \\
\hline $\mathrm{Cd}$ & $\leq 0,01$ & $5,0 \cdot 10^{-3}$ & $3,0 \cdot 10^{-3}$ \\
\hline $\mathrm{As}$ & $\leq 0,0005$ & $4,7 \cdot 10^{-4}$ & $2,0 \cdot 10^{-4}$ \\
\hline $\mathrm{Hg}$ & $\leq 0,010$ & $8,2 \cdot 10^{-3}$ & $2,6 \cdot 10^{-3}$ \\
\hline $\mathrm{Pb}$ & $\leq 0,1$ & $\leq 5,0 \cdot 10^{-4}$ & $\leq 5,0 \cdot 10^{-4}$ \\
\hline $\mathrm{Co}$ & $\leq 0,02$ & $7,3 \cdot 10^{-3}$ & $5,3 \cdot 10^{-3}$ \\
\hline $\mathrm{Ni}$ & $\leq 0,01$ & $\leq 5,0 \cdot 10^{-4}$ & $\leq 5,0 \cdot 10^{-4}$ \\
\hline $\mathrm{Se}$ & & & \\
\hline
\end{tabular}

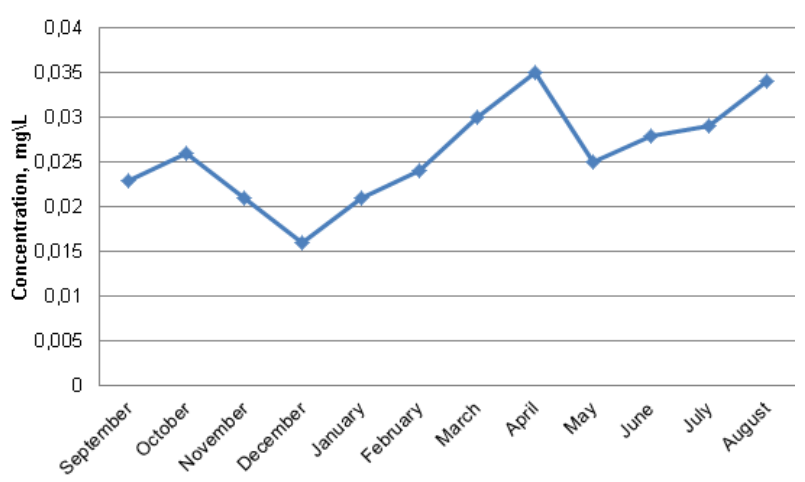

Fig. 3. Concentrations of trace element $\mathrm{Mn}$ in Tap water from Karachuny Reservoir.

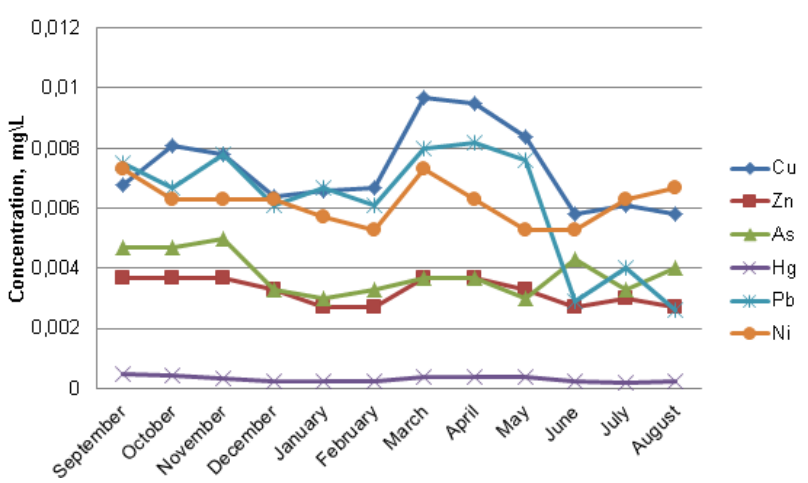

Fig. 4. Monitoring of trace element content in tap water from Karachuny Reservoir.

Changes in concentrations of trace elements $\mathrm{Cu}, \mathrm{Zn}$, $\mathrm{As}, \mathrm{Hg}, \mathrm{Pb}$, Ni during the year are shown in Figure 4.

There are no curves that showed the content of trace elements $\mathrm{Cd}, \mathrm{Co}$ and Se in drinking water which is under study on the figure 4 , because the presence of cadmium 
was not established by this method of study, and selenium and cobalt gave as a result low permanent data in their determination.

As shown in the figure 4 , the concentration maxima for most trace elements occur in the spring season. The reason may be the ingress of polluted melt water and industrial emissions into Karachuny Reservoir during this period.

Trace elements $\mathrm{Zn}$, Co and Se were founded in fairly low concentrations in drinking water. Their reduced content in water can lead to increased accumulation of iron, copper and cadmium in the human body and to frequent colds and infectious diseases [8, 16-18].

The reliability of the obtained results was verified using statistical methods of analysis with the calculation of such elementary mathematical statistics as the sample mean variance, standard deviation (Table 1-4), confidence interval, limits of confidence interval (Table 6).

Table 6. The limits of confidence interval $\dot{\mathrm{x}} \pm \Delta \dot{\mathrm{x}}$

\begin{tabular}{|c|c|c|c|c|c|c|c|}
\hline & Mn & $\mathbf{C u}$ & $\mathbf{P b}$ & Zn & As & $\mathbf{N i}$ & $\mathrm{Cu}$ \\
\hline & $2,3 \cdot 10^{-2}$ & $6,8 \cdot 10^{-3}$ & $7,5 \cdot 10^{-3}$ & $3,7 \cdot 10^{-3}$ & $4,7 \cdot 10^{-3}$ & $7,3 \cdot 10^{-3}$ & $6,8 \cdot 10^{-3}$ \\
\hline 0 & \pm & \pm & \pm & \pm & \pm & \pm & \pm \\
\hline & $2,8 \cdot 10^{-3}$ & $4,9 \cdot 10^{-4}$ & $4 \cdot 10^{-4}$ & $1,1 \cdot 10^{-4}$ & $1,1 \cdot 10^{-4}$ & $1,1 \cdot 10^{-4}$ & $4,9 \cdot 10^{-4}$ \\
\hline & $2,6 \cdot 10^{-}$ & $8,1 \cdot 10^{-3}$ & $6,7 \cdot 10^{-3}$ & $3,7 \cdot 10^{-3}$ & $4,7 \cdot 10^{-3}$ & $6,3 \cdot 10^{-3}$ & $8,1 \cdot 10^{-3}$ \\
\hline \multirow[t]{2}{*}{1} & \pm & \pm & \pm & \pm & t & \pm & \pm \\
\hline & $5,6 \cdot 10^{-3}$ & $7,0 \cdot 10^{-4}$ & $1,0 \cdot 10^{-3}$ & $1,1 \cdot 10^{-4}$ & $1,1 \cdot 10^{-4}$ & $1,1 \cdot 10^{-3}$ & $7,0 \cdot 10^{-4}$ \\
\hline & $2,1 \cdot 10^{-2}$ & $7,8 \cdot 10^{-3}$ & $7,8 \cdot 10^{-3}$ & $3,7 \cdot 10^{-3}$ & $5,0 \cdot 10^{-3}$ & $6,3 \cdot 10^{-3}$ & $7,8 \cdot 10^{-3}$ \\
\hline \multirow[t]{2}{*}{1} & \pm & \pm & \pm & \pm & \pm & \pm & \pm \\
\hline & $2,8 \cdot 10^{-3}$ & $1,3 \cdot 10^{-3}$ & $5,6 \cdot 10^{-4}$ & $1,1 \cdot 10^{-4}$ & $1,8 \cdot 10^{-4}$ & $1,1 \cdot 10^{-4}$ & $1,3 \cdot 10^{-3}$ \\
\hline \multirow{3}{*}{1} & $1,6 \cdot 10^{-2}$ & $6,4 \cdot 10^{-3}$ & $6,1 \cdot 10^{-3}$ & $3,3 \cdot 10^{-3}$ & $3,3 \cdot 10^{-3}$ & $6,3 \cdot 10^{-3}$ & $6,4 \cdot 10^{-3}$ \\
\hline & \pm & \pm & \pm & \pm & \pm & \pm & \pm \\
\hline & $2,1 \cdot 10^{-3}$ & $1,1 \cdot 10^{-3}$ & $3,7 \cdot 10^{-4}$ & $1,1 \cdot 10^{-4}$ & $1,1 \cdot 10^{-4}$ & $1,1 \cdot 10^{-4}$ & $1,1 \cdot 10^{-3}$ \\
\hline & $2,1 \cdot 10^{-2}$ & $6,6 \cdot 10^{-3}$ & $6,7 \cdot 10^{-3}$ & $2,7 \cdot 10^{-3}$ & $3,3 \cdot 10^{-3}$ & $5,7 \cdot 10^{-3}$ & $6,6 \cdot 10^{-3}$ \\
\hline \multirow[t]{2}{*}{0} & \pm & \pm & 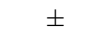 & \pm & 1 & \pm & \pm \\
\hline & $6,4 \cdot 10^{-3}$ & $5,5 \cdot 10^{-4}$ & $1,3 \cdot 10^{-4}$ & $4,3 \cdot 10^{-4}$ & $1,1 \cdot 10^{-4}$ & $1,1 \cdot 10^{-4}$ & $5,5 \cdot 10^{-4}$ \\
\hline & $2,4 \cdot 10^{-2}$ & $6,7 \cdot 10^{-3}$ & $6,1 \cdot 10^{-3}$ & $2,7 \cdot 10^{-3}$ & $3,3 \cdot 10^{-3}$ & $5,3 \cdot 10^{-3}$ & $6,7 \cdot 10$ \\
\hline \multirow[t]{2}{*}{0} & \pm & \pm & \pm & \pm & \pm & \pm & \pm \\
\hline & $1,8 \cdot 10^{-3}$ & $1,6 \cdot 10^{-4}$ & $6,6 \cdot 10^{-4}$ & $1,1 \cdot 10^{-4}$ & $1,0 \cdot 10^{-4}$ & $6,1 \cdot 10^{-4}$ & $1,6 \cdot 10^{-3}$ \\
\hline \multirow{3}{*}{03} & $3,0 \cdot 10^{-2}$ & $9,7 \cdot 10^{-3}$ & $8,0 \cdot 10^{-3}$ & $3,7 \cdot 10^{-3}$ & $3,7 \cdot 10^{-3}$ & $7,3 \cdot 10^{-3}$ & $9,7 \cdot 10^{-3}$ \\
\hline & \pm & \pm & \pm & \pm & \pm & \pm & \pm \\
\hline & $2,8 \cdot 10^{-3}$ & $3,7 \cdot 10^{-4}$ & $8,4 \cdot 10^{-4}$ & $1,1 \cdot 10^{-4}$ & $1,1 \cdot 10^{-4}$ & $1,1 \cdot 10^{-3}$ & $3,7 \cdot 10^{-4}$ \\
\hline \multirow{3}{*}{04} & $3,5 \cdot 10^{-2}$ & $9,5 \cdot 10^{-3}$ & $8,2 \cdot 10^{-3}$ & $3,3 \cdot 10^{-3}$ & $3,7 \cdot 10^{-3}$ & $6,3 \cdot 10^{-3}$ & $9,5 \cdot 10$ \\
\hline & \pm & \pm & \pm & \pm & \pm & \pm & \pm \\
\hline & $2,1 \cdot 10^{-3}$ & $9,7 \cdot 10^{-4}$ & $5 \cdot 10^{-4}$ & $1,1 \cdot 10^{-4}$ & $1,1 \cdot 10^{-4}$ & $3,1 \cdot 10^{-4}$ & $9,7 \cdot 10$ \\
\hline \multirow{3}{*}{05} & $2,5 \cdot 10^{-2}$ & $8,4 \cdot 10^{-3}$ & $7,6 \cdot 10^{-3}$ & $3,3 \cdot 10^{-3}$ & $3,0 \cdot 10^{-3}$ & $6,3 \cdot 10^{-3}$ & $8,4 \cdot 10^{-3}$ \\
\hline & \pm & \pm & \pm & \pm & \pm & \pm & \pm \\
\hline & $3,8 \cdot 10^{-3}$ & $7,6 \cdot 10^{-4}$ & $1,1 \cdot 10^{-4}$ & $1,1 \cdot 10^{-4}$ & $1,0 \cdot 10^{-4}$ & $3,1 \cdot 10^{-4}$ & $7,6 \cdot 10^{-4}$ \\
\hline \multirow{3}{*}{06} & $2,8 \cdot 10^{-2}$ & $5,8 \cdot 10^{-3}$ & $2,9 \cdot 10^{-3}$ & $2,7 \cdot 10^{-3}$ & $4,3 \cdot 10^{-3}$ & $5,3 \cdot 10^{-3}$ & $5,8 \cdot 10^{-3}$ \\
\hline & \pm & \pm & \pm & \pm & \pm & \pm & \pm \\
\hline & $8,7 \cdot 10^{-3}$ & $7,6 \cdot 10^{-4}$ & $7,4 \cdot 10^{-4}$ & $6,0 \cdot 10^{-4}$ & $2,1 \cdot 10^{-4}$ & $1,1 \cdot 10^{-4}$ & $7,6 \cdot 10^{-4}$ \\
\hline \multirow{3}{*}{07} & $2,9 \cdot 10^{-2}$ & $6,1 \cdot 10^{-3}$ & $4,0 \cdot 10^{-3}$ & $3,0 \cdot 10^{-3}$ & $3,3 \cdot 10^{-3}$ & $6,3 \cdot 10^{-3}$ & $6,1 \cdot 10^{-3}$ \\
\hline & \pm & \pm & \pm & \pm & \pm & \pm & \pm \\
\hline & $2,8 \cdot 10^{-3}$ & $4,6 \cdot 10^{-4}$ & $7,0 \cdot 10^{-4}$ & $1,5 \cdot 10^{-4}$ & $1,1 \cdot 10^{-4}$ & $3,8 \cdot 10^{-4}$ & $4,6 \cdot 10^{-4}$ \\
\hline \multirow{3}{*}{08} & $3,4 \cdot 10^{-2}$ & $5,8 \cdot 10^{-3}$ & $2,6 \cdot 10^{-3}$ & $2,7 \cdot 10^{-3}$ & $4,0 \cdot 10^{-3}$ & $6,7 \cdot 10^{-3}$ & $5,8 \cdot 10^{-3}$ \\
\hline & \pm & \pm & \pm & \pm & \pm & \pm & \pm \\
\hline & $1,1 \cdot 10^{-3}$ & $0 \cdot 10^{-4}$ & $7,0 \cdot 10^{-4}$ & $1,1 \cdot 10^{-4}$ & 70.0 & 1.10 & $1,0 \cdot 10^{-4}$ \\
\hline
\end{tabular}

Statistical analysis of the monitoring results showed the absence of gross errors in the statistical sample data, all the values of the successive measurements are within the confidence interval. Therefore, the established content of trace elements in water samples can be considered close to true.

\section{Conclusions}

Monitoring of trace elements in the tap water from the Karachuny Reservoir showed that the content of any trace element that was selected for the study did not exceed the maximum permissible concentration during the year.

For trace elements of manganese, plumbum and cuprum, a noticeable fluctuation of the content was observed. Maximum values were fixed for manganese in April $\left(3,5 \cdot 10^{-2} \mathrm{mg} / \mathrm{dm}^{3}\right)$ and August $\left(3,4 \cdot 10^{-2} \mathrm{mg} / \mathrm{dm}^{3}\right)$; for cuprum $\left(9,7 \cdot 10^{-3}-9,5 \cdot 10^{-3} \mathrm{mg} / \mathrm{dm}^{3}\right)$ and plumbum $\left(8,0 \cdot 10^{-3}-8,2 \cdot 10^{-3} \mathrm{mg} / \mathrm{dm}^{3}\right)$ in March.

Minimum values were fixed for manganese in December $\left(1,6 \cdot 10^{-2} \mathrm{mg} / \mathrm{dm}^{3}\right)$; for cuprum $\left(5,8 \cdot 10^{-3}\right.$ $\left.\mathrm{mg} / \mathrm{dm}^{3}\right)$ and plumbum $\left(2,6 \cdot 10^{-3}-2,9 \cdot 10^{-3} \mathrm{mg} / \mathrm{dm}^{3}\right)$ in June-August.

The content of other trace elements was changing more smoothly and remained about an average value during the year. The average annual concentrations of these trace elements in water which was under study were: $\mathrm{Zn}-3,24 \cdot 10^{-3} \mathrm{mg} / \mathrm{dm}^{3} ; \mathrm{As}-3,87 \cdot 10^{-3} \mathrm{mg} / \mathrm{dm}^{3}$; $\mathrm{Hg}-3,2 \cdot 10^{-4} \mathrm{mg} / \mathrm{dm}^{3} ; \mathrm{Ni}-6,28 \cdot 10^{-3} \mathrm{mg} / \mathrm{dm}^{3}$.

Thus, drinking water in Kryvyi Rih in terms of the trace elements content of cadmium, plumbum, cuprum, arsenic, nickel, zinc, manganese, mercury, selenium and cobalt meet the normative requirements for the quality of drinking water and they are safe for human consumption.

However, the low content of trace elements zinc, cobalt and selenium in drinking water makes its quality worse. People should use other ways of delivering these trace elements to the body (a varied diet, vitamin complexes).

\section{References}

1. Zakon Ukrayini, Pro pitnu vodu, pitne vodopostachannya ta vodovidvedennya. Vidomosti Verkhovnoyi Radi Ukrayini 16 (2002), https://zakon.rada.gov.ua/laws/show/2918-14. Accessed 26 Dec 2019

2. Nacionalna dopovid pro yakist pitnoyi vodi ta stan pitnogo vodopostachannya v Ukrayini u 2018 roci (2018), http://www.minregion.gov.ua/wpcontent/uploads/2019/11/Proekt-Nats.-dop.-za2018.pdf. Accessed 26 December 2019

3. Derzhavni sanitarni normi ta pravila 2.2.4-171-10 (2010)

4. I.V. Huschuk, O.I. Brezetska, V.I. Huschuk, R.R. Drab, Enviroment \& Health 1 (2018)

5. T.N. Kotkova, N.I. Fedyuchka, A.O. Picil, Naukovij visnik NLTU Ukrayini 27, 10 (2017)

6. I.M. Andrusishina, Voda i vodoochisni tehnologiyi. Naukovo-tehnichni visti·16, 1 (2015)

7. A.V. Kudrin, Immunofarmakologiya mikroelementov (KMK, Moskva, 2000) 
8. A.V. Skalnyj, Himicheskie elementy $v$ fiziologii $i$ ekologii cheloveka (Mir, Moskva, 2004)

9. A.A. Bedzaj, O.N. Sherbina, I.A. Sherbina, B.M. Mihalichko, Visnik Lvivskogo derzhavnogo universitetu bezpeki zhittyediyalnosti 10 (2014)

10. L. Prashanth, K.K. Kattapagari, R.T. Chitturi, V.R. Baddam, L.K. Prasad, J NTR Univ Health Sci. 4, (2015)

11. Sana Arab, Asia Alshikh. Nature and Science 8, 10 (2010)

12. D. Demetriades, A. Economou, A. Voulgaropoulos, Analytica chimica acta 519, 2 (2004)

13. P. Chooto, P. Wararatananurak, C. Innuphat ScienceAsia 36 (2010)

14. J. Zhuang, L. Zhang, W. Lu, D. Shen, R. Zhu, D. Pan, Int. J. Electrochem. Sci. 6 (2011)

15. MBB 081/12-4631-00 (1998)

16. E.V. Salnikova, Vestnik OGU 10, 146 (2012)

17. M.K. Yadrick, M.A. Kenney, E.A. Winterfeldt, Am J. Clin. Nutr. 49 (1989)

18. L.N. Tretyak, E.M. Gerasmov, Vestnik OGU 12 (2007) 